\title{
Initial Growth of Seedlings of Diferent Pineapple Cultivars in Boa Vista, RR
}

\author{
Desenvolvimento Inicial de Mudas de Diferentes Cultivares de Abacaxi no Município de Boa \\ Vista, RR
}

\author{
Deyse Cristina Oliveira da Silva*a; Sandra Catia Pereira Uchôa $a^{\mathrm{a}}$ José Maria Arcanjo Alves ${ }^{\mathrm{a}}$; Valdinar Ferreira Melo \\ Cineone Nascimento da Silvab; Glauber Ferreira Barreto ${ }^{\mathrm{b}}$ \\ ${ }^{a}$ Universidade Federal de Roraima. RR, Brasil. \\ bUniversidade Federal de Roraima. Programa de Pós-Graduação Stricto Sensu em Agronomia. RR, Brasil. \\ *E-mail: deyse_cris@hotmail.com
}

\begin{abstract}
Currently, the commercial pineapple cultivation in Brazil relies almost exclusively on the cultivars Smooth Cayenne and Pérola. However, both are susceptible to fusariosis. Develment of new cultivars, that are both acceptable to the export market and resistant to fusariosis, is essential for the continued crop success. The objective of this study was to evaluate early vegetative development of five micropropagation-derived pineapple cultivars (BRS Ajubá, BRS Imperial, IAC Fantástico, Pérola and BRS Vitória). Seedlings were produced and acclimatized at the Biomudas Biotechnology Laboratory, Venda Nova do Imigrante, Espírito Santo, Brazil, and were then transported to Boa Vista, Roraima, for the experiments. Here they were placed in a greenhouse under controlled climatic conditions and a completely randomized design implemented, using a subdivided plots scheme, with the micro-porpergation generated seedlings. Location randomized within plots, and evaluation running for five different periods $(30,60,90,120$ and 150 days after transplant - DAT) in the subplots, with fifteen replicates. Evaluated vegetative development variables weere: plant height, rosette diameter, number of leaves, "D" leaf length and width, as well as percentage survival at experiment end. Cultivars IAC Fantástico and Pérola showed greater vegetative development than BRS Ajubá, BRS Imperial and BRS Vitória. The cultivars IAC Fantástico and Pérola, due to their greater precocity, can be transplanted to a final growth location 30 days after seedling transplantion into a greenhouse, while other cultivars require 150 DAT occur.
\end{abstract}

Keywords: Plants Acclimation. Seedlings Growth. In vitro Cultivation. Fruit Growing. Pineapple Micropropagation .

\section{Resumo}

Atualmente, no Brasil, o cultivo do abacaxizeiro, em escala comercial, é quase que exclusivamente com as cultivares Smooth Cayenne e Pérola, no entanto, ambas são suscetíveis a fusariose. A inserção de novas cultivares, com aceitação no mercado de exportação e resistente à fusariose é imprescindivel para o sucesso da cultura. O objetivo deste estudo foi avaliar o desenvolvimento vegetativo precoce de cinco cultivares de abacaxi derivadas de micropropagação (BRS Ajubá, BRS Imperial, IAC Fantástico, Pérola e BRS Vitória). As mudas foram produzidas e aclimatizadas no Laboratório de Biotecnologia Biomudas, localizado em Venda Nova do Imigrante - ES, sendo posteriormente transportadas para Boa Vista, RR para implantação do experimento, onde foram conduzidas à casa de vegetação, sob condições climáticas controladas. Utilizou-se o delineamento inteiramente casualizado, em esquema de parcelas subdivididas, sendo cinco cultivares de abacaxizeiro (BRS Ajubá, IAC Fantástico, BRS Imperial, Pérola e BRS Vitória), oriundas de micropropagação, aleatorizadas nas parcelas e cinco épocas de avaliação (30, 60, 90, 120 e 150 dias após o transplantio - DAT) nas subparcelas, com quinze repetições. As variáveis de desenvolvimento vegetativo avaliadas foram: altura da planta, diâmetro da roseta, número de folhas, comprimento e largura de folha "D", além da percentagem de sobrevivência, ao final do experimento. As cultivares IAC Fantástico e Pérola apresentaram maior desenvolvimento vegetativo em relação à BRS Ajubá, BRS Imperial e BRS Vitória. As cultivares IAC Fantástico e Pérola, em razão da maior precocidade, podem ser transplantadas para local definitivo a partir de 30 DAT das mudas em casa de vegetação, as demais cultivares requerem 150 DAT.

Palavras-chave: Aclimatação de Plantas. Crescimento de Mudas. Cultivo in vitro. Fruticultura. Micropropagação de Plantas.

\section{Introduction}

In Brazil, the area given to fruit production occupies a total of 2.2 million hectares. This is distributed across the national territory, and generates some 5.6 million jobs, so emplying $34 \%$ of the rural labor force (IBGE, 2018). On a global scale, Brazil is the third largest fruit producer country in the world, behind only China and India (ANUÁRIO BRASILEIRO DE FRUTICULTURA, 2018).

Among tropical fruits, pineapple (Ananas comosus (L.) Merril) stands out as being the most widely-cultivated in the world, with the largest producers being: Costa Rica (2.7 million tons), Brazil (2.5 million tons), The Philippines (2.4 million tonnes), Thailand (2.2 million tonnes) and Indonesia
(1.8 million tonnes). The Brazilian production of this fruit is concentrated mainly in the states of Pará, Paraíba, Minas Gerais, Bahia and Rio de Janeiro, with a planted area of 68.618 ha (FAO, 2017). The commercial cultivation of this species in Brazil, almost exclusively involves the cultivars Smooth Cayenne and Pérola (SAMPAIO et al., 2011), both of which are susceptible to fusariosis.

As part of this vision, the following cultivars have been introduced in Brazil: BRS Imperial, 2003; BRS Vitória, 2006; BRS Ajubá, 2009 and IAC Fantástico, 2010. All of them show promising edibility characteristics when fresh and are resistant to fusariosis.

One of the challenges for the pineapple grower who wants 
to diversify his production is difficulty obtaining quality seedlings, which is due to the low effectiveness of propagation methods. Because of the crop cycle and the high cost of production, this complicates access to seedlings, as well as resulting in a higher final price. Development of new and improved propagation techniques, which are more efficient, flexible and easy to impliment are key to providing abundant, cheap, but high-quality, pineapple seedlings (COELHO et al., 2007).

In this context, tissue culture has emerged with rapid clonal propagation, regeneration and multiplication of trait-superior, genetically engineered, clones and ex situ conservation of germplasm all combining to facilitate production of a variety of crops. In vitro propagation uses plant-specific tissues, and has a number of advantages over traditional methods of plant propagation. Among these are the large number of plants that can be raised in a small space, and the production of healthy and genetically uniform seedlings (HOPKINS, 2007).

The problem of seedling production without good quality can be solved by micropropagation or in vitro propagation, which allows the production of good quality genetic and phytosanitary material, increasing productivity and crop quality (BARREIRO NETO, 2009). However, these seedlings need to undergo an acclimatization process immediately after removal from the in vitro environment. At this stage, crop management should be done with the utmost care, as plants are more sensitive to environmental conditions such as light and temperature, as well as crop treatments such as fertilization, irrigation, growth regulators and substrates. Micropropagated plants have slower initial growth and underestimated productivity in their first cycle (FREITAS, 2010).

It is well-known that more vigorous seedlings are more likely to produce more productive crops. There is, therefore, a need to evaluate the initial vegetative development of micropropagation-derived seedlings, before taking them to the field. Consequently, the objective of this study was to evaluate early vegetative development of five micropropagationderived pineapple cultivars (BRS Ajubá, BRS Imperial, IAC Fantástico, Pérola and BRS Vitória).

\section{Material and Methods}

Experiments began in January 2015, when seedlings had a mean height of $12 \pm 2 \mathrm{~cm}$. The plants used in the experiment were provided by the Biotechnology Laboratory BIOMUDAS, Venda Nova do Imigrante, Espírito Santo, Brazil. After the arrival of the specimens in Boa Vista, Roraima, Brazil (at the approximate age of 90 days of micropropagation), seedlings were transplanted to small tubs, each $5.0 \mathrm{~cm}$ diameter, $19.0 \mathrm{~cm}$ height and $300 \mathrm{~cm}^{3}$ volume, filled with a substrate composed of carbonized rice husk and earthworm húmus in a 2:1 ratio. Seedlings were arranged on benches in a greenhouse at the Agrarian Sciences Center of the Federal University of Roraima (CCA/UFRR), for the seedlings to adapt and reach uniform size.

At 50 days after transplant (DAT), seedlings were transferred to $500 \mathrm{~cm}^{3}$ pots, all containing a substrate identical to the initial composition. For the last 120 days of the experiment seedlings remained under forced ventilation, at a temperature of $28 \pm 2^{\circ} \mathrm{C}$, and $80 \%$ relative humidity, and received two daily waterings of five minutes each, through an automated micro-sprinkler system.

The experimental design was completely randomized via a subdivided plot scheme, with 15 replicates. In the plots, five pineapple cultivars (BRS Ajubá (AJB), IAC Fantástico (FANT), BRS Imperial (IMP), Pérola (PER) and BRS Vitória (VIT); were randomized, and days after transplanting (30, 60, 90, 120 and 150 DAT) were designated as subplots. Each experimental unit was composed of three plants.

Fertilization was carried out, exclusively, via foliar feed. Concentrations of $10 \mathrm{~g} \mathrm{~L}^{-1}$ urea, $5 \mathrm{~g} \mathrm{~L}^{-1}$ potassium chloride and $0.5 \mathrm{~g} \mathrm{~L}^{-1}$ boric acid were used as sources of $\mathrm{N}, \mathrm{K}$ and $\mathrm{B}$, respectively. Fertilizer was applied weekly, with localized sprays of $5 \mathrm{ml}$ per plant, up to $90 \mathrm{DAT}$, and then $10 \mathrm{ml}$ per plant until the end of the experiment at 150 DAT, concentrations adapted from the Fertilizer and Lime Recommendation System for Pineapple- FERTCALC-Abacaxi (SILVA et al., 2009) and experiments performed by Bregonci et al., (2008).

Throughout experiment irrigation occurred at intervals pre-programmed by the greenhouse automated system, with two daily five-minute waterings each. At 30 and 90 DAT, a preventive application of Cercobin 700 WP systemic

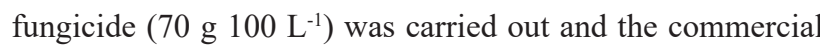

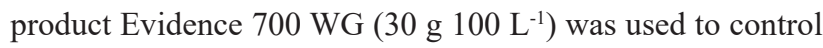
scale insects.

During each experimental period the following variables were measured:a) plant height $(\mathrm{cm})$, measured with a ruled graduated in millimeters, from the base of the plant to the extremity of the largest leaf; b) diameter of the rosette $(\mathrm{cm})$, measured with graduated callipers, in millimeters, among the largest opposing leaves; c) number of leaves, obtained by counting all the leaves visible in each plant, without detaching them or harming their structure; d) length of leaf " $D$ " (cm), measured with a ruler graduated in millimeters from the base to the apex of the most developed leaf; e) width of leaf " $D$ " $(\mathrm{cm})$, measured with graduated ruler, in millimeters, among the edges of the widest part of the most developed leaf; $f$ ) percentage of seedling survival (\%), calculated by deducting from the total number of experimental plants the number that had died by 150 DAT.

The obtained results were submitted to analysis of variance, Tukey's test for the comparisons among the cultivars and regression for the periods $(p \leq 0.05)$, using the program SISVAR (FERREIRA, 2014). The model for each variable was selected by considering the significance of the parameter coefficients and the highest $\mathrm{R}^{2}$ values. 


\section{Results and Discussion}

Analysis of variance indicated that the interaction between pineapple cultivars and evaluation periods was significant $(p \leq 0.05)$ for all the variables analyzed, except for the percentage of plant surviving, which showed only significant difference among the cultivars. Comparison among the cultivars, within each time period and for the variables studied, is shown in Table 1. At 30 DAT, by which time adaptation of the seedlings to the environment has occured, it was found that the seedlings of cv. PER had noticably greater height, rosette diameter and "D"leaf length, signaling general robustness. On the other hand, seedlings of cv. VIT showed the poorest results for the same variables, indicating that this cultivar is vulnerable to prevailing conditions in the initial phase.

Table 1 - Mean values for plant height, rosette diameter, number of leaves length of "D" leaf and width of "D" 1 eaf at 30, 60, 90, 120 and 150 days after transplanting (DAT) for five pineapple cultivars, Boa Vista, Roraima State, Brazil

\begin{tabular}{|c|c|c|c|c|c|}
\hline \multirow{3}{*}{ Cultivares } & \multicolumn{5}{|c|}{ Evaluation Periods } \\
\hline & 30 DAP & 60 DAP & 90 DAP & 120 DAP & 150 DAP \\
\hline & \multicolumn{5}{|c|}{ Height $(\mathrm{cm})$} \\
\hline AJB & $13.08 \mathrm{~b}^{*}$ & $13.79 \mathrm{c}$ & $17.24 \mathrm{~d}$ & $22.50 \mathrm{~d}$ & $23.53 \mathrm{~d}$ \\
\hline FANT & $18.38 \mathrm{a}$ & $20.65 \mathrm{a}$ & $27.25 \mathrm{a}$ & $33.92 \mathrm{a}$ & $34.28 \mathrm{a}$ \\
\hline IMP & $14.71 \mathrm{~b}$ & $16.08 \mathrm{~b}$ & $20.89 \mathrm{c}$ & $26.05 \mathrm{c}$ & $26.84 \mathrm{c}$ \\
\hline PER & $19.91 \mathrm{a}$ & $20.72 \mathrm{a}$ & $23.51 \mathrm{~b}$ & $27.96 \mathrm{~b}$ & $29.69 \mathrm{~b}$ \\
\hline \multirow[t]{2}{*}{ VIT } & $11.25 \mathrm{c}$ & $12.79 \mathrm{c}$ & $13.87 \mathrm{e}$ & $18.11 \mathrm{e}$ & $20.60 \mathrm{e}$ \\
\hline & \multicolumn{5}{|c|}{ Rosette diameter $(\mathrm{cm})$} \\
\hline AJB & $1.05 \mathrm{ab}$ & $1.65 \mathrm{a}$ & $2.05 \mathrm{a}$ & $3.39 \mathrm{bc}$ & $3.73 \mathrm{~b}$ \\
\hline FANT & $0.89 \mathrm{bc}$ & $1.88 \mathrm{a}$ & $2.19 \mathrm{a}$ & $3.49 \mathrm{ab}$ & $3.95 \mathrm{~b}$ \\
\hline IMP & $0.99 \mathrm{bc}$ & $1.84 \mathrm{a}$ & $2.13 \mathrm{a}$ & $3.22 \mathrm{c}$ & $3.72 \mathrm{~b}$ \\
\hline PER & $1.28 \mathrm{a}$ & $1.69 \mathrm{a}$ & $2.09 \mathrm{a}$ & $3.68 \mathrm{a}$ & $4.29 \mathrm{a}$ \\
\hline \multirow[t]{2}{*}{ VIT } & $0.79 \mathrm{c}$ & $1.38 \mathrm{~b}$ & $1.73 \mathrm{~b}$ & $2.44 \mathrm{~d}$ & $3.13 \mathrm{c}$ \\
\hline & \multicolumn{5}{|c|}{ Number of leaves } \\
\hline AJB & $13.07 \mathrm{~b}$ & $17.33 \mathrm{a}$ & $23.87 \mathrm{a}$ & $26.93 \mathrm{a}$ & $29.07 \mathrm{a}$ \\
\hline FANT & $13.73 \mathrm{~b}$ & $18.07 \mathrm{a}$ & $22.80 \mathrm{a}$ & $26.87 \mathrm{a}$ & $29.73 \mathrm{a}$ \\
\hline IMP & $17.33 \mathrm{a}$ & $19.07 \mathrm{a}$ & $24.47 \mathrm{a}$ & $28.33 \mathrm{a}$ & $30.33 \mathrm{a}$ \\
\hline PER & $9.80 \mathrm{c}$ & $12.27 \mathrm{c}$ & $16.80 \mathrm{c}$ & $20.53 \mathrm{c}$ & $23.20 \mathrm{c}$ \\
\hline \multirow[t]{2}{*}{ VIT } & $12.87 \mathrm{~b}$ & $14.07 \mathrm{~b}$ & $20.00 \mathrm{~b}$ & $23.80 \mathrm{~b}$ & $26.47 \mathrm{~b}$ \\
\hline & \multicolumn{5}{|c|}{ Width of "D" leaf $(\mathrm{cm})$} \\
\hline AJB & $12.39 \mathrm{c}$ & $13.03 \mathrm{~cd}$ & $16.11 \mathrm{c}$ & $19.07 \mathrm{c}$ & $20.43 \mathrm{c}$ \\
\hline FANT & $15.81 \mathrm{~b}$ & $17.49 \mathrm{~b}$ & $22.21 \mathrm{a}$ & $28.23 \mathrm{a}$ & $29.63 \mathrm{a}$ \\
\hline IMP & $13.13 \mathrm{c}$ & $13.95 \mathrm{c}$ & $17.65 \mathrm{~b}$ & $19.74 \mathrm{c}$ & $21.45 \mathrm{c}$ \\
\hline PER & $19.54 \mathrm{a}$ & $20.09 \mathrm{a}$ & $21.31 \mathrm{a}$ & $22.53 \mathrm{~b}$ & $23.40 \mathrm{~b}$ \\
\hline \multirow[t]{2}{*}{ VIT } & $10.05 \mathrm{~d}$ & $11.65 \mathrm{~d}$ & $14.27 \mathrm{~d}$ & $16.00 \mathrm{~d}$ & $17.03 \mathrm{~d}$ \\
\hline & \multicolumn{5}{|c|}{ Length of "D" leaf (cm) } \\
\hline AJB & $1.23 \mathrm{c}$ & $2.36 \mathrm{bc}$ & $3.26 \mathrm{ab}$ & $3.61 \mathrm{~b}$ & $3.83 \mathrm{~b}$ \\
\hline FANT & $1.98 \mathrm{a}$ & $2.66 \mathrm{a}$ & $3.49 \mathrm{a}$ & $3.75 \mathrm{ab}$ & $4.01 \mathrm{ab}$ \\
\hline IMP & $1.61 \mathrm{~b}$ & $2.35 \mathrm{c}$ & $3.15 \mathrm{~b}$ & $3.27 \mathrm{c}$ & $3.57 \mathrm{c}$ \\
\hline PER & $1.42 \mathrm{bc}$ & $2.61 \mathrm{ab}$ & $3.37 \mathrm{ab}$ & $3.97 \mathrm{a}$ & $4.15 \mathrm{a}$ \\
\hline VIT & $1.42 \mathrm{bc}$ & $1.81 \mathrm{~d}$ & $2.33 \mathrm{c}$ & $2.67 \mathrm{~d}$ & $2.95 \mathrm{~d}$ \\
\hline
\end{tabular}

Cultivars : AJB - BRS Ajubá; FANT - IAC Fantástico; IMP - BRS Imperial; PER - Pérola; VIT - BRS Vitória. * Means followed in the column by the same lowercase letter do not differ from each other at $5 \%$ probability (Tukey test).

Source: Research data

On the last day, 150 DAT, which preceded transplanting into field systems, it was noted that cv. PER ceased to have the greatest height and length of "D" leaf values, but still has the largest rosette diameter. Seedlings of cv. FANT and PER had the highest potential for producing robust plants in the field.

Over analysed time pineapple cultivar growth data fitted a linear growth model. For height (Figure 1A), cultivars FANT and IMP had the greatest average daily increments, with $\mathrm{cv}$. FANT slightly ahead. However, the rapid growth of $\mathrm{cv}$. PER between 0 and 30 DAP, should be noted, as during this time it practically doubled its height. From 30 DAP, however, its height increment rate decreased, dropping to only around 2.5 $\mathrm{cm}$ per month, this being close to that observed for cultivars AJB and VIT. 
Figure 1 - Height of the plant $(\mathrm{cm})(\mathrm{A})$ and diameter of the leaf rosette $(\mathrm{cm})(\mathrm{B})$ of pineapple cultivars, by cultivation duration. Cultivars: AJB - BRS Ajubá; FANT - IAC Fantástico; IMP - BRS Imperial; PER - Pérola; VIT - BRS Vitória.

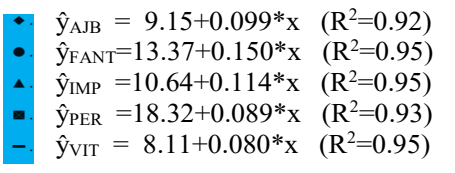

A

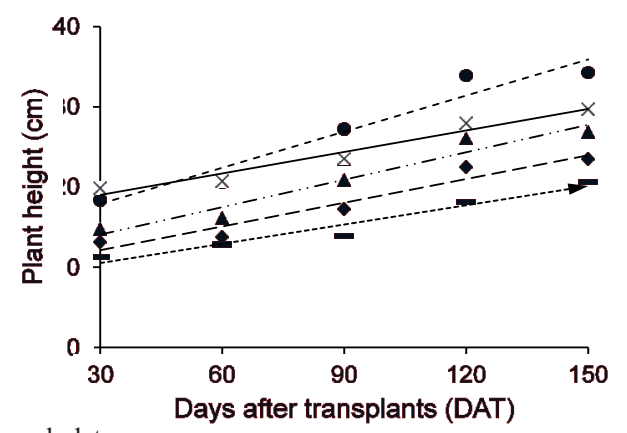

Source: Research data.

Regardless of the individual cultivar performances, at 150 DAT, all seedlings had heights close to or greater than $20 \mathrm{~cm}$ (Figure 1A), and so were suitable for transplanting out to field conditions. Seedlings with a height less than 20 $\mathrm{cm}$ can be difficult to handle, especially during weeding and irrigation, when it is difficult to avoid soil or substrate entering the pineapple rosette. This can result in death of the apical bud and the undesirable development of lateral shoots (VENTURA et al., 2009). Considering $20 \mathrm{~cm}$ as the minimum height for transplanting to final location, then cvs. PER and FANT had already achieved such condition in the early stages of evaluation, while cv. VIT required 150 DAT.

For rosette diameter, the cultivars differed significantly from each other at 30 DAT, except FANT and IMP, which had statistically similar averages (Table 1). Mean daily increments were higher for cvs PER and FANT (0.026 cm per day) and lowest for the cv. VIT. The high performance of cv. PER (4.29 $\mathrm{cm}$ ) was especially notable when compared to the cv. VIT, which had the smallest rosette diameter at 150 DAT $(3.13 \mathrm{~cm})$.

The rapid plant development in diameter has implications for shortening the production cycle. This has commercial applications, since producers use leaf rosette diameter to determine the most appropriate time to induce inforescence production (SAMPAIO et al., 2011). There was little difference in rosette diameter increment among the cultivars (Figure 1B), indicating that, in general, the slow vegetative pineapple growth is inherent to cultivars forms. Rodrigues et al. (2010) mornitoring vegetative development up to 240 DAT, reported that the first 150 DATs constitute the stage of root growth and establishment, which will be used in the water and nutrientes absorption, and leaves, which will be used for photosynthesis (AZEVEDO et al., 2007).

The number of leaves increased as a function of the evaluation periods (Figure 2). At 150 DAT, cv. IMP had the greatest number of leaves (31.03) and cv. PER (23.55) the lowest, differing significantly from the other cultivars. At

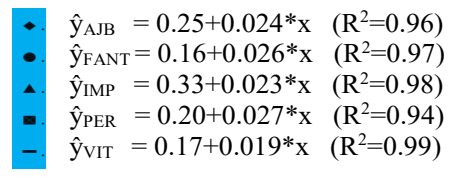

B

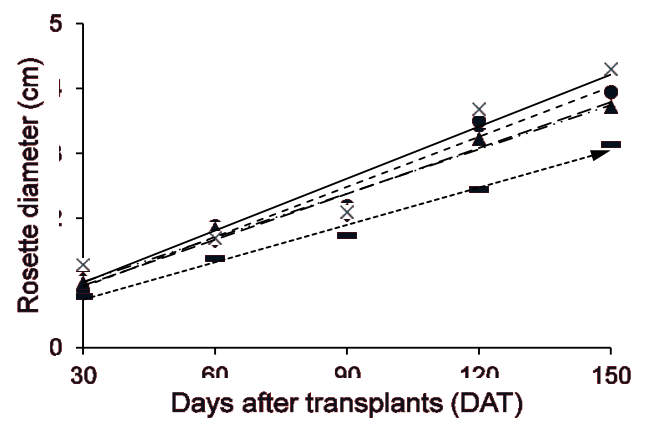

60 DAT, the cultivars IMP, AJB and FANT had the greatest number of leaves, and were all statistically undifferentiated. Such results demonstrate that vegetative development attributes vary among the cultivars.

Figure 2 - Number of leaves per pineapple cultivar, as a funtion of experimental time periods. Cultivars: AJB - BRS Ajubá; FANT - IAC Fantástico; IMP - BRS Imperial; PER - Pérola; VIT - BRS Vitória
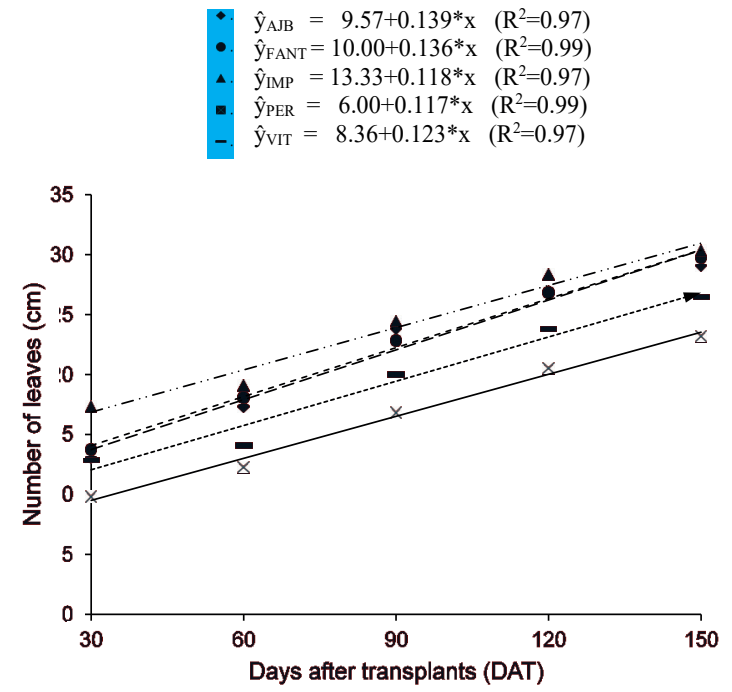

Source: Research data.

For leaf number, Spironello et al. (2010) allied the high vigor of the FANT cultivar to leaf producion, and noted that this was comparable to that of the cultivar Smooth Cayenne which also produces a large number of leaves.

For cv. PER, Siebeneichler et al. (2008) attributed the reduced number of leaves to the higher spacing among the leaves, though this is compensated for by the greatest leaf length. This characteristic was reported by Siebeneichler et al. (2008) at the time of floral induction, when plants had 25 to 30 leaves.

In studies of pineapple cv. IMP, Oliveira et al. (2015) found that more leaves were producted between 180 and 
240 DAP, than between 120 and 180 DAP, but that this subsequently decreased between 240 and 300 DAP. In the current study, it was observed the emission of 27 leaves from 120 to $300 \mathrm{DAP}$, and the IMP cultivar produced some 14 leaves between DAT 30 to 150 . This agrees with the periodicity of leaf production given by Oliveira et al. (2015) for this cultivar.

In terms of length of leaf " $D$ ", seedlings of the pineapple cultivar FANT benefited from extended post-transplantation greenhouse time, as leaves initially measuring $15 \mathrm{~cm}$, had doubled their length by 150 DAP, to reach a mean of 30.36 $\mathrm{cm}$. This contrasts with results for $\mathrm{cv}$. VIT, which had the lowest " $D$ " leaf length values, with a mean of $10.14 \mathrm{~cm}$ being recorded for the first evaluation period and $17.46 \mathrm{~cm}$ at 150 DAP, a mean "D" leaf length increase of only $7.32 \mathrm{~cm}$ across the entire experimental period (Figure 3A).

Figura 3 - Length (A) and width (cm) (B) of leaf "D" for pineapple cultivars, as a function of experimental timesperiods. Cultivars: AJB - BRS Ajubá; FANT - IAC Fantástico; IMP - BRS Imperial; PER - Pérola; VIT - BRS Vitória
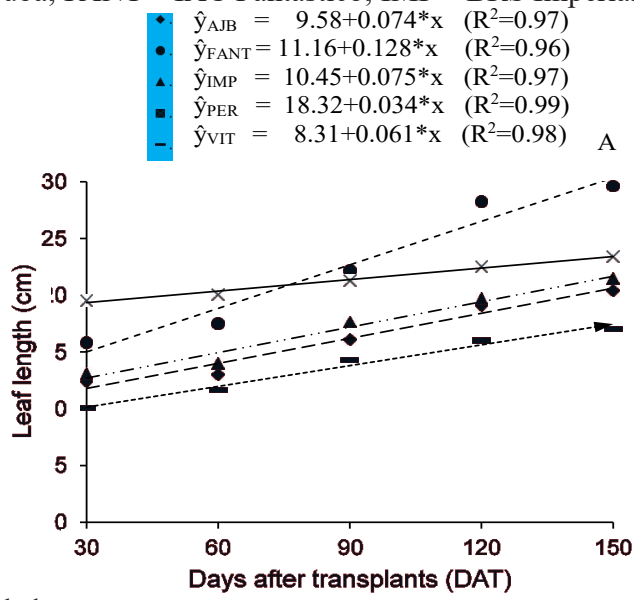

Source: Research data.

At 150 DAT, it was found that, although the cultivars FANT and PER had a statistically different number of leaves, they both had longer leaves. This, and the fact that they require greater between-leaf spacing for development, may explaining the high rates of height and rosette diameter growth observed, as well as the reduced number of leaves. On the other hand, cv. VIT, which had the lowest mean " $D$ " leaf length at experimental period end, also showed slower growth rates for the other traits than other cultivars did (Table 1).

Lower growth rates by cv. VIT was also reported by Cardoso et al. (2013), who compared the cultivar BRS Vitória with Pérola and Smooth Cayenne. These authors found that an increase in cultivation time provided a linear increase in "D" leaf length for cv. VIT. However, the highest value found for this metric, at $540 \mathrm{DAP}$, was $64 \mathrm{~cm}$, a figure well below those recorded for the other cultivars was used in the study. However, for the cultivar BRS Vitória, Silva et al. (2012) recorded values of 81.4 at 420 DAP.

Regarding the "D" leaf width in response to different evaluation period, there was an increasingly linear behavior to all the studied cultivars (Figure 3B).. The cultivars PER and FAN had the greatest leaf widths, with mean values of 4.51 and $4.18 \mathrm{~cm}$, respectively, at 150 days after transplanting, while cv. VIT had a mean width of $3.01 \mathrm{~cm}$.

According to Ventura et al. (2009), technical guidelines growing BRS Vitória pineapples, are the same as those used by producers for Pérola and Smooth Cayenne cultivars, and it shows similar patterns of growth, development and size cv. Pérola.
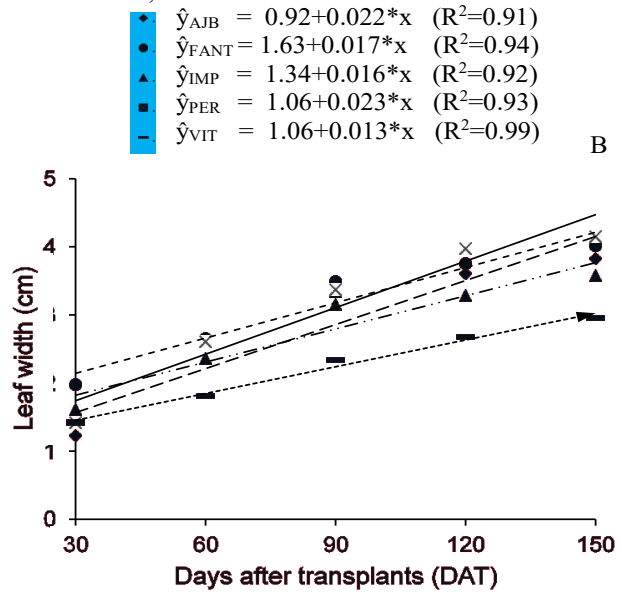

However, this was not observed in the current experiment, since for practically all the characteristics evaluated, cv. VIT gave values well below those recorded for cv. PER.

Experiments with cv. VIT pineapples conducted by Cardoso et al. (2013) found that there was a linear increase in with increasing cultivation time for such growth characteristics as leaf number, "D" leaf length and stem diameter, which is in agreement with the results of the current study.

Seedlings of FANT, IMP and PER cultivars survived through all stages of the experiment (100\% survival), and AJB had a good percentage of survival, 95\%. In contrast, VIT had only $35 \%$ survival, indicating high seedling fragility under the conditions used in by the current study (Figure 4).

Figure 4 - Survival percentages of pineapple cultivars at 150 DAP. Cultivars: AJB - BRS Ajubá; FANT - IAC Fantástico; IMP - BRS Imperial; PER - Pérola; VIT - BRS Vitória

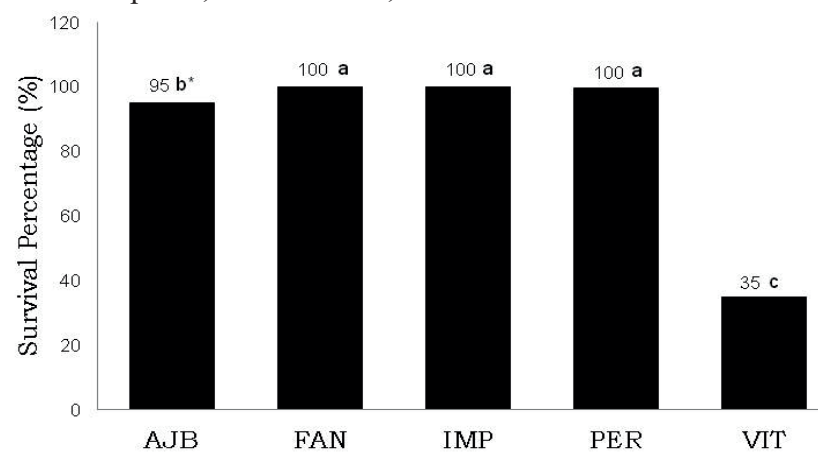

*Means followed by the same letter do not differ from each other at $5 \%$ probability (Tukey test)

Source: Research data 
These differences in survival among cultivars indicates that the AJB, FANT, IMP and PER cultivars are more robust and adaptable to the conditions in which they were cultivated, when compared to cv. VIT. This is important because the success of pineapple farming is mainly due to the adaptability to tropical and subtropical regions, often under quite rustic consitions (CRESTANI et al., 2010).

Regardless of the cultivar used, producers must take morphological and agronomic characteristics into account when raising pineapples, and be aware that each cultivar responds differently to the treatments used for this crop. By being selective, a producer can choose plants that give high yields and good quality fruits (GUARÇONI; VENTURA, 2011; MELÃO et al., 2015).

The dominance of a small number of pineapple cultivars in commercial plantations poses various risk to the crop, including phytosanitary problems and lack of choice for the demanding consumer (POMMER; BARBOSA, 2009). To reduce such problems, varietal diversification is recommended, but this must have a solid basis on the capacities of the varieties involved to adapt to both the cultivation sites of the plants and the market destinations of their fruits.

\section{Conclusion}

The cultivars IAC Fantástico and Pérola showed better vegetative development, growth characteristics and overall robustness than cvs. BRS Ajubá, BRS Imperial and BRS Vitória.

The cultivars IAC Fantástico and Pérola, showed best early growth, and so they can be transplanted to a final location 30 days after initial seedlings greenhouse transplantiation. Other tested cultivars can be moved 150 days after initial transplantion.

The cv. BRS Vitória had the lowest survival and initial growth rates of any of the studied cultivars, so that new cultivar-specific studies are suggested.

\section{References}

ANUÁRIO BRASILEIRO DE FRUTICULTURA 2018. Santa Cruz do Sul: Gazeta, 2018.

AZEVEDO, P. V. et al. Walter requirements of pineapple crop grown in a tropical environment, Brazil. Agric Water Manag, v. 88 , n. 1-3, p. 201-208, 2007. doi:10.1016/j.agwat.2006.10.021

BREGONCI, I. S. et al. Adubação foliar com macro e micronutrientes no crescimento de mudas micropropagadas do abacaxi cv. Gold [Ananas comosus (L.) Merrill] em diferentes recipientes. Ciênc. Agrotec., v.32, n.3, p.705-711, 2008.

CARDOSO, M. M. et al. Crescimento do abacaxizeiro 'vitória' irrigado sob diferentes densidades populacionais, fontes e doses de nitrogênio. Rev. Bras. Frutic., v.35, n.3, p.769-781, 2013. doi: 10.1590/S0100-29452013000300014

COELHO, R. I. et al. Resposta à adubação com ureia, cloreto de potássio e ácido bórico em mudas do abacaxizeiro 'Smooth Cayenne'. Rev. Bras. Frutic., v. 29, n.1, p.161-165, 2007. doi: $10.1590 / \mathrm{S} 0100-29452007000100033$
CRESTANI, M. et al. Das Américas para o Mundo - origem, domesticação e dispersão do abacaxizeiro. Cienc. Rural, v.40, n.6, p.1473-1483, 2010. doi: 10.1590/S0103-84782010000600040

FAO - Food and Agriculture Organization of the United Nations. FAOSTAT - Production. (2016). http://faostat3.fao.org/faostatgateway/go/to/download/Q/*/E

GUARÇONI M., A.; VENTURA, J. A. Adubação N-P-K e o desenvolvimento, produtividade e qualidade dos frutos do abacaxi 'Gold' (MD-2). Rev. Bras. Cienc. Solo, v.35, p.1367-1376, 2011. doi: 10.1590/S0100-06832011000400031

FERREIRA, D. F. Sisvar: a guide for its bootstrap procedures in multiple comparisons. Cienc Agrotec, v.38, n.2, p.109-112, 2014. doi: 10.1590/S1413-70542014000200001

HOPKINS, W. Plant biotechnology: the Green World Series. New York: Infobase Publishing, p. 36-39, 2007.

IBGE (Instituto Brasileiro de Geografia e Estatística). Levantamento sistemático da produção agrícola. (2018).

MATOS, A. P. et al. Integrated Management of Fusariosis in Pineapple Fields under Integrated Production System. Acta Hortic., v. 822, p. 199-204, 2009. doi:10.17660/ActaHortic.2009.822.24

MELÃO, A. V. et al. Caracterização agronômica e divergência genética entre acesso de abacaxizeiro nas condições do estado do Mato Grosso. Rev. Bras. Frutic., v. 37, p. 952-960, 2015. doi: 10.1590/0100-2945-218/14

OLIVEIRA, A. M. G. et al. Adubação N-K no abacaxizeiro 'BRS-Imperial': Efeito no desenvolvimento e na floração da planta. Rev. Bras. Frutic., v. 37, n. 3, p. 755-763, 2015. doi: 10.1590/0100-2945-023/14

POMMER, C.V.; BARBOSA, W. The impacto f breeding on fruit production in warm climates of Brazil. Rev. Bras. Frutic., v. 31, n. 2, p. 612-634, 2009. doi:10.1590/S0100-29452009000200043

RODRIGUES, A.A. et al. Desenvolvimento vegetativo de abacaxizeiros 'Pérola' e 'Smooth Cayenne' no estado da Paraíba. Rev. Bras. Frutic., v.32, n.1, p.126-134, 2010. doi:10.1590/ S0100-29452010005000031

SAMPAIO, A. C.; FUMES, T. F.; LEONEL, L. Crescimento vegetativo e características dos frutos de cinco cultivares de abacaxi na região de Bauru- SP. Rev. Bras. Frutic., v. 33, n. 3, p. 816-822, 2011. doi:10.1590/S0100-29452011005000101

SIEBENEICHLER, S. C.; MONNERAT, P. H.; SILVA, J. A. Deficiência de boro na cultura do abacaxi 'Pérola'. Acta Amazon., v. 38, n. 4 , p. $651-656,2008$.

SPIRONELLO, A. Abacaxi. In: DONADIO. L.C. (Org.). História da fruticultura paulista. Jaboticabal: Sociedade Brasileira de Fruticultura, 2010.

SILVA, A. P. et al. Sistema de recomendação de fertilizantes e corretivos para a cultura do abacaxi - FERTCALC-abacaxi. Rev. Bras. Cienc. Solo, v.33, p.1269-1280, 2009. doi: 10.1590/S010006832009000500020

SILVA, A. L. P. et al. Resposta do abacaxizeiro 'Vitória' a doses de nitrogênio em solos de tabuleiros costeiros da Paraíba. Rev. Bras. Frutic., v.36, n.2, p.447-456, 2012. doi: 10.1590/S010006832012000200014

VENTURA, J.A.; COSTA, H.; CAETANO, L.C.S. Abacaxi 'vitória': uma cultivar resistente à fusariose. Rev. Bras. Frutic., v.31, n.4, p.931-1233, 2009. doi: 10.1590/S010029452009000400001 